\title{
Cluster approach in the strategy of innovative development of organization in conditions of stable regional development
}

\author{
Yevgeniy Moiseevich Bukhvald \\ Institute of Economics under Russian Academy of \\ Science \\ Moscow, Russia \\ buchvald@mail.ru
}

\author{
Nikita Sergeevich Verkhovov \\ Saint-Petersburg Polytechnic University after \\ Peter the Great \\ Higher School of cyber-physical systems and \\ management \\ Saint-Petersburg, Russia \\ nikita5555@bk.ru
}

\author{
Alexander Vasilievich Biryukov \\ Volgograd State Technical University, \\ Faculty of economics and management \\ Volgograd, Russia \\ helenderbet@mail.ru
}

\begin{abstract}
Russia has been realizing lately the importance of cluster approach in handling issues of modernization and technological development of innovative economy. The article assesses the Cluster approach as a strategic basis of innovative development of organization in conditions of stable regional development, outlining problems and shortcomings in cluster development of the Russian economy.
\end{abstract}

Keywords- cluster, Cluster approach, economy of knowledge, innovative development, strategy

\section{INTRODUCTION}

In the Russian legislation now, there is no comprehensive definition of cluster approach, and you can come across notion cluster in separate ministerial acts. [1]

The idea of modern cluster approach to development of knowledge economy is to enable various stake holders (business society, public and scientific organizations, authorities, educational, financial institutions) to consolidate their efforts on uniting a large number of competing organizations in a cluster. [2] It is presumed that successful cooperation of rivals can boost the economic growth and social development both of separate regions and of the country as a whole.

\section{Materials AND Methods (Model)}

The role of clusters for knowledge economy can be explained as follows:[3]

- by various effects, resulting from joint activity of different economic entities, improving the labour productivity. Included here are such effects as split of labour, scale effect, savings on transaction costs, free exchange of information and technological transfer, as well as synergy effect;

- clusters help harmonize the interests of manufacturers, consumers and regional authorities;

- integration of different enterprises and organizations forms favourable environment for new combinations of resources, developing and implementing new ideas, setting up new innovative organizations; 
- uniting resources of cluster participants facilitates solution of innovative development problems, which can hardly be overcome by separate economic entities;

- Formed within the framework of clusters are hospitable conditions for setting up and developing new businesses, realizing new joint ventures.

- clusters as "points of growth" based on multiplication effect positively influence the regional economy, providing a qualitative leap forward in the regional development and improving a number of social \& economic indices, regional trade balance, quality of life, employment, Gross regional product etc.;

- Cluster approach makes it possible to realize the idea of continuous training and improve the level of personnel by introducing specific competence for existing and future employees.

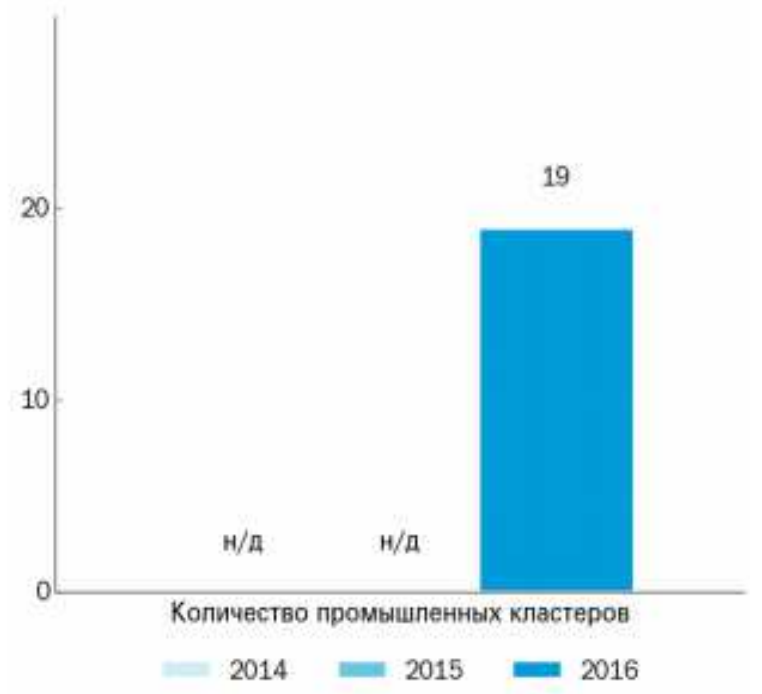

Рис. 1 - Cluster quantity dynamics

A number of foreign countries have accumulated big experience in implementing innovative policy, mainly through cluster approach to stable development of regions and knowledge economy.

The world practice manifests fairly robust development of cluster approach during the last two decades. By now, clusters cover about $50 \%$ of economy in the leading countries of the world. Data on the number of clusters in 2016 are given in Fig 1.
Table 1 - Geographic location of clusters in 2016

\begin{tabular}{|l|l|l|l|l|}
\hline Category & Total & $\begin{array}{l}\text { High } \\
\text { level }\end{array}$ & $\begin{array}{l}\text { Medium } \\
\text { level }\end{array}$ & $\begin{array}{l}\text { Initial } \\
\text { level }\end{array}$ \\
\hline $\begin{array}{l}\text { Privolzhskiyй } \\
\text { Federal Okrug }\end{array}$ & 7 & 1 & 2 & 4 \\
\hline $\begin{array}{l}\text { Central } \\
\text { Federal Okrug }\end{array}$ & 5 & 0 & 2 & 3 \\
\hline $\begin{array}{l}\text { North- } \\
\text { Western } \\
\text { Federal Okrug }\end{array}$ & 4 & 0 & 0 & 4 \\
\hline $\begin{array}{l}\text { Siberian } \\
\text { Federal Okrug }\end{array}$ & 1 & 0 & 0 & 1 \\
\hline $\begin{array}{l}\text { Ural Federal } \\
\text { Okrug }\end{array}$ & 1 & 0 & 0 & 1 \\
\hline $\begin{array}{l}\text { North } \\
\text { Caucasus } \\
\text { Federal Okrug }\end{array}$ & 1 & 0 & 0 & 1 \\
\hline $\begin{array}{l}\text { Southern } \\
\text { Federal Okrug }\end{array}$ & 0 & 0 & 0 & 0 \\
\hline $\begin{array}{l}\text { Far-Eastern } \\
\text { Federal Okrug }\end{array}$ & 0 & 0 & 0 & 0 \\
\hline
\end{tabular}

Leading positions by the number of clusters are held by Kaluga region (2), Ulianovsk region (2). A pioneer of innovative clusters is considered to American Silicon valley, accommodating about 87 thousand companies, 40 research centres and a dozen universities, the largest of which is Stanford. The university and private sector are involved in continuous exchange of information by "innovation charged" personnel. The cluster uses services of a third of US venture companies (180 companies), 47 investment and 700 commercial banks, funding one way or another the financial operations of companies. The scope of innovative activity allowed the Silicon valley to become a leader in national export, accounting for $40 \%$ of export trade in California. Technical regions of the whole world are trying to copy the valley's example, imitating even names: Silicon plateau in Bangalore (India), Silicon island in Taiwan, Silicon swamp in Israel.

Key provisions of the modern regional cluster concept are outlined in Methodical recommendations on implementing cluster policy in the Russian Federation subjects and are detailed in programs, projects and legislation at the Federal and regional levels [4]. The Cluster policy provides for a system of state and social tools and mechanisms to develop cluster initiatives. The targets are: higher 
competiveness of regions, economic entities, included in the cluster, as well as development of market infrastructure, promoting implementation of innovations.

The Strategy of innovative development in the Russian Federation up to 2020 contains the formation processes of territorial \& production clusters, facilitating development of high technology in prioritized industries, realizing competitive potential of poorly developed territories, specialized in raw materials processing and energy generation, using modern technologies, creating clusters, which concentrate high innovative technologies with traditionally developed industrial complex.

\section{RESULTS AND DISCUSSION}

Modern Russian universities play an important role in the development of innovative economy, knowledge economy and technologies, as well as in the regional development [6, c. 148]. New innovative structures appear in the sphere of education and science: clusters, techno-parks, technological platforms, scientific \& innovative educational complexes, industrial complexes and industrial parks, business incubators etc. All these innovative organizational \& legal forms have their specific features $[7$, p. 36]. The choice of this or that form depends upon the deliverables, characteristics and strategic targets of a territory in question, its social \& economic, demographic and environmental features as well as nature of business.

Nowadays there are rising public expectations from modern universities [8, c. 81]. A higher role is played by innovative components of modern universities: they are called upon not only to train professional specialists for production and science, managers of new industries. Universities become profitable organizations by performing scientific survey on a wide range of production and commercial application.

Modern economy is characterized by globalization and mobility of manpower and intellectual elite. Scientists have got an opportunity to be engaged in research and use of resources, cooperating not only between separate organizations inside a country, but also in joint survey with foreign colleagues [9, p. 171]. This results in more intensive exchange of knowledge, new joint international publications, new products and technologies, new jobs in high-tech. industries.

Economy of countries, which provide assistance and create financial and organizational \& economic conditions for development of innovations and their implementation, have a potential to speed up the economic growth in the long-term perspective.

The cluster approach has gained popularity over the last decade as organizational form of innovative activity. The cluster approach was first implemented in the USA and proved its feasibility, as it prompted the creation of mutually beneficial system of interaction between science and education, business and state. Modern clusters are a common technological chain, producing innovative products. The cluster unites on the same territory scientists-inventors, investment companies and specialized manufacturers.

\section{CONCLUSION}

Modern Russian cluster and techno-parks are created on the initiative of the government, scientific organizations, investors and innovation companies. Creation and development in Russia of such organizational form as innovative cluster, innovative techno-parks, technological platforms will contribute to formation of active business environment, combining investments with new ideas and inventions, closer managerial and operation cooperation between Federal and regional authorities, regional universities and industry. Cluster structures facilitate realization of state obligations regarding fundamental science as a corner stone of educational, scientific, technical and technological development.

- creating conditions for development of capital intensive scientific survey and production, joining efforts aimed at critical technologies, being in high demand of the modern growing economy; 
- higher level of education and training of students, as young scientists, students and post graduates are actively involved in creation and propagation of new knowledge;

- integrating natural scientific and humanitarian knowledge, as students, studying natural scientific subjects have an opportunity to learn commerce of precise quality: these are special approaches and mechanisms of commercial activity in the sphere of knowledge intensive industry;

- better competiveness of Russian industry, creating new high tech jobs.

Techno-park and cluster structures are registered as share property of municipality, university, associations, corporations, small or medium business companies. Some innovative structures in regions are formed by the government initiative, some with support of regional authorities, business and industry. Survey of concrete organizational and management forms, used by innovative structures, sources of their funding, commercialization of technologies has already been performed by Russian scientists. However, still pending are issues of motivation by profitability in various innovative forms of business organization.

As compared to developed countries, in Russia this process is just gaining momentum and has good perspectives.

\section{References}

[1] About national nanotechnology network: the government of the Russian Federation of April 23, 2010 № 282

[2] Tarasenko V. Territorial clusters. Seven instruments -Alpina publisher, 2015. 202 p - - ISBN 978-5-9614-4705-7

[3] Lenchuk E. B., Vlaskin G. A. Cluster approach in the strategy of innovative development of foreign countries [Electronic resource]

http://institutiones.com/strategies/1928-

klasternyj-podxod-v-strategii-innovacionnogorazvitiya-zarubezhnyx-stran.html (date of application 12.03.2017)

[4] Methodical recommendations on implementation of cluster policy in Subjects of the Russian Federation / UTV. Ministry of economic development 26.12.2008 № 2-615 AK/D19.

[5] Nabatova S. A., V. A. Nabatova CLUSTER APPROACH IN the DEVELOPMENT of the KNOWLEDGE ECONOMY AND TECHNOLOGIES // Economics and modern management: theory and practice: collection of articles in mater. LVII international. science.- practice. Conf. No. 1 (55). - Novosibirsk: Sibak, 2016.

[6] Kostyleva S. Yu., Institute of higher education in the context of economic development // Questions of modern science and practice. University them. V. I. Vernadsky. 2013. No. 1 (45). C. 148-154.

[7] Kostyleva S. Yu. Institutional and economic mechanism of coordination of interests of higher school and high-tech business in Russia // Socio-economic phenomena and processes. 2015. Vol. 10. No. 5. C. 36-42.

[8] Kostyleva S. Yu., the Influence of globalization processes on economic development of the Russian system of higher education // Questions of modern science and practice. University them. V. I. Vernadsky. 2015. No. 3 (57). C. 81-88.

[9] Kostyleva S. Yu., Tolmacheva E. V. the Role of human potential of science in improving the effectiveness of institutional reforms of higher education: conclusions for economic policy. Vestnik tambovskogo universiteta. Series: Humanitarian Sciences. 2015. No. 5 (145). C. 171-177.

[10] Factors of sustainable development of Russian regions: monograph / V. V. Sinicyna, Gayfutdinova O. S., etc. / ed. by S. S. Chernov. - Book 6. - Novosibirsk: CRS, 2009. - 326 p.

[11] Our common future // Report of the world Commission on environment and development (MCOR). - Moscow: Progress, 1989.

[12] Official site of Federal state statistics service http://www.gks.ru/ 